\title{
Shifting Global Economic Paradigm
}

\author{
Abdul Ghafoor Awan
}

Dean of Faculties, Institute of Southern Punjab, Multan, Pakistan

\begin{abstract}
Introduction: The $21^{\text {st }}$ century was started with the dawn of a new economic puzzle of China's fast economic growth. It has surprised the economists. The Chinese constant upward growth has shifted economic paradigm and the axis of growth appear to have been shifted from the western hemisphere to the eastern hemisphere. Some economists term it a $21^{\text {st }}$ century miracle. The author has determined to test this miracle through empirical framework.

Research Question: Main research question of this study to explore the answer of the question why China is recording consistent rapid economic growth? Is this growth in the same way as other developed countries experienced in the past or is it a new phenomenon-a shift in global economic paradigm.

Objectives: The objective of this empirical analysis is to investigate into the causes of fast economic growth of China in the context whether this growth pattern is a normal phenomenon or an indicator of shifting global economic paradigm.

Methodology: Our study is spread over a period starting from 1980 to 2011 because of the introduction of economic reforms and massive economic growth. We have collected data from different sources such as China Bureau of National Statistics, IMF, World Bank and relevant research Journals and books. The selected variables for this research paper are: labour productivity, investment, exports, Research and Development expenses, capital stock, open door policy, real exchange rate and US GDP. We used ordinary least square (OLS) model to measure change in the selected variables. Five tests were used to test the stability of the model.

Findings: The Econometric results show that international trade and investment in capital stock and R\&D expenses by Chinese Government are the major determinants, which are responsible for enhancing labour productivity and output in the long-run, Similarly, real exchange rate appears as an important determinant to explain change in output in the long-run.
\end{abstract}

Keywords: China, Labor productivity, Investment, R\&D, Open door policy, Exports, Output

\section{INTRODUCTION}

The vertical economic growth of China during last four decades is not less than a miracle in the history of Economics. China recorded an average 8 percent GDP growth The GDP growth during 1963-1978, in spite of the failure of the" Great Leap Forward" and " The Cultural Revolution" Policies. Moreover, this growth momentum has speeded up since the start of 1980s and is still continued till 2013 when the average annual growth rate was fluctuated between 10 and more than 7 percent. This growth phenomenon is unmatchable with other big economies of the world. The upward growth in the Chinese GDP has substantially contributed into the world GDP because its share in international trade has jumped from less than $0.5 \%$ in 1960 to $10 \%$ in 2013 .

There are numerous factors that that are responsible for China's economic growth. But important among them are: savings and investment, which has increased to around $45 \%$ and 35\% respectively against 20 percent in 1950s and 1960s. However, capital accumulation has not shown substantial impact on the improvement of total factor productivity (TFP) (Chow, 1993), De Long et al. (1992). However, with the beginning of a series of economic and institutional reforms in 1978, China's impressive export performance has initiated debate about the role of exports in Economic growth. Public policies and institutional restructuring were the driving forces that transformed the whole economic, financial and social systems. However, the transformation process was well-thought and it was executed gradually to obtain desired results. Specifically, the policy of opening economy for foreign direct investment and liberalization were risky. But the Chinese leadership implemented these policies successfully to accelerate growth momentum. The shift from planned economy to semi-open economy has brought revolutionary changes in the Chinese economy and society. This process reached its peak gradually in 2001 when China joined the World Trade Organization (WTO). It was the major event that shift world trade paradigm.

\section{Research Question}

Main research question of this study is to explore the answer of the question, why China is recording consistent rapid economic growth? Is this growth in the same way as other developed countries experienced in the past or is it a new phenomenon-a shift in global economic paradigm. 


\section{Objectives}

The objective of this empirical analysis is to investigate into the causes of fast economic growth of China in the context whether this growth pattern is a normal phenomenon or an indicator of shifting global economic paradigm.

\section{Data and Source}

In this study we have used secondary data collected from different sources such China's Bureau of National Statistics, IMF and World Bank database, relevant books and research journals, Robert and Lee database.

\section{Study Period}

Our study period is spread over 48 years, from 1962 to 2010. This period is almost free from economic and political turmoil, having socio-economic stability and tranquility.

\section{Variables}

We have selected the following variables for our study. We will measure the changes in these variables during the period 1962-2010 in the context of the economic growth of China:-

- China's labour productivity and output in the short and long-run.

- Capital accumulation.

- Exports.

- Openness.

- Research and Development outlay.

- Technological progress.

- Real exchange rates.

- Savings rates.

- Investment.

- $\quad$ Trade relations with the United States.

\section{Hypothesis}

The hypotheses of our study are as under:-

- Whether the Chinese growth was the result of investment made before and after reforms period.

- Whether the Chinese growth was due to opening of economy and expansion of export sector.

- Whether change in real exchange rate affects the exports.

\section{Estimation Techniques}

We used Ordinary Least Square (OLS) method to measure the strength of relations among the selected variables. We used time series data analysis techniques to measure change in selected variables during the study period.

\section{Distinguishing Characteristics of the Study}

This study is different from previous empirical studies in three ways:-

- Innovation and capital formation complement each other and international trade is assumed to be the main source of accelerating economic activities;

- In Chinese economic growth investment has played a key role both in pre-reform and post-reform periods. During pre-reform period the volume of export was low while its share was increased substantially in post-reform period.

- The export sector is the main driving force of Chinese economic growth and speed of investment in manufacturing sector.

\section{LITERATURE REVIEW}

Classical economists, such as Adam Smith (1776), David Ricardo (1817), Thomas Malthus (1798), Frank Ramsey (1928), Joseph Schumpeter (1934) and Frank Knight (1944) were the per pounders of the modern theories of economic growth. Their ideas are related to the basic approach of competitive behavior and equilibrium dynamics, the role of diminishing returns and its relations to physical and human capital, the interplay between per capita GDP and population the growth rate, the effects of technological progress in the form of increased specialization of labor and discoveries of new products and methods of production, and the role of monopoly power as an incentive for technological progress. The modern growth theory was started from the classical article of Ramsey (1928). Ramsey's inter-temporally separate utility function is as widely used today as the Coo-Douglas production function. His model was not accepted by the economists till the 1960s. Harrod (1939) and Domar (1946) made efforts to co-relate Keynesian theory with the determinants of economic growth. Their approach was that capitalist system is inherently unstable and their suggested production function has no substitutability among the inputs. The Solow (1956) and Swan (1956 was the core contribution because this model is the neoclassical form of the production function that postulate constant returns to scale, declining returns to each input, positive and smooth elasticity of substitution between the inputs and a constant-saving rate to generate simple general equilibrium model .These model predict conditional convergence that states the faster growth rate depends on lower the starting levels of per capita GDP, relative to the long-run or steady-state level. It further states that countries having less capital per worker relative to their long run capital per worker tend to have higher rates of return and higher growth rates. The convergence is conditional due to three reasons: (i) Population growth rate, (ii) Capital and output depends on saving rate, (iii) and the of the production function. The work of Romer (1986), Lucas (1988) played a catalytic role in the research on economic growth which got attention of the Economists since 1980s. In their work, they have given a central place to human capital to perpetuate economic growth. According to them, human capital helps slower the process of depreciation and declining return on capital stock.

The difference between 1960s research and 1990s research on growth is that the former is theoretical in nature while the latter is data-based empirical analysis. The applied research was used to establish relation between theory and data. However, old theories such as endogenous growth 
theories were tested by applying empirical techniques. This approach is known neoclassical growth model of conditional convergence. The focus of 1990s empirical research was assessment of the robustness of the kinds of estimates, the role of increasing returns, R\&D spending, human capital, and technological progress. The question facing by the economists is that whether an economy can enjoy positive growth rates forever on the basis of increasing saving and investment as well as accumulating capital stock. A cross-country data for the period $f$ 19692000 indicate that the average real per capital GDP growth per annum for 112 countries was 1.8 percent and average ratio of gross investment to GDP was 16 percent. However, empirical results for 38 sub-Saharan African countries are quite different where the average growth rate was only 0.6 percent and the average investment ratio was only 10 percent. The results for nine East Asian "tigers" showed that there was an average 4.9 percent growth rate and the average investment ratio was 25 percent. These observations suggest that growth and investment rates are positively related (Sala-i-Martin et al, (2004).

\section{Methodology Of Research}

\section{Empirical Framework}

Now we initiate empirical analysis with a general and the least possible conditional assumptions, thus allowing the data to reveal the nature of the interactions among them. From these relationships, it is possible to advance with the hypothesis about the nature and causes of the forces that have stimulated the rapid economic growth in China in recent decades. Our empirical analysis basically uses Chinese annual data for the period 1980-2011 derived from the NBS of China which has currently published the latest compilation of the Chinese economy in 2010. Our data set consists of GDP (lgdp), labor productivity - output per worker- (lprod), investment (linv), exports in FOB terms (lexp), R\&D expenditure (lrd) of the Chinese economy, $t$ and the real exchange rate (lrer). All variables are in logs and real terms, and have been deflated by the GDP deflator.

The real exchange rate has been calculated using the nominal exchange rate between the Chinese currency and the US \$ (Renminbi/\$) and the consumer price indices (CPIs).Although data are available from China since 1952, we preferred to move to the beginning of the effective sample until 1980 because the period of 1980-2011 was an era of rapid expansion of Chinese GDP due to introduction of economic reforms in different sectors and gradually opening the economy for foreign direct investment.

\section{Data Sources, Type and Range}

The authors have collected time series data for the periods from 1980 to 2011 from Chinese economy. Data sources are official websites and documents published by government of China that is World Development Indicators.

\section{Model description}

The present study pursues the following model of real gross domestic product;

\section{$\mathrm{RGDP}=\mathrm{f}$ (RCAP, REX, REXP)}

In the above equation, RGDP stands for Real Gross domestic product calculated in million Chinese currency Renminbi , RCAP shows Real Gross fixed capital formation in million taken as proxy for capital, REX denotes Real Official Exchange Rate in millions, REXP indicates real exports of goods of services in millions. In economics, Cob - Douglas form of production function is widely used to represent the relationship of an output to input. We have also chosen Cob - Douglas form of the output model which is engraved as;

\section{$R G D P=\alpha R C A P^{\beta} R E X^{\gamma} R E X P^{\delta}$}

In the above model, $\beta$ is output elasticity of capital, $\gamma$ is output elasticity of exchange rate, $\delta$ is output elasticity of exports and $\alpha$ is total factor productivity. To estimate the above model appropriately, we have to take its natural log. Finally, we have drawn the following model to be estimated now;

$$
\begin{aligned}
& \ln R G D P=\ln \alpha+\beta \ln R C A P+\gamma \ln R E X+\delta \ln R E X P+\mu \\
& R G D P_{t}^{*}=\alpha^{*}+\beta R C A P_{t}^{*}+\gamma R E X_{t}^{*}+\delta R E X P_{t}^{*}+\mu_{t}
\end{aligned}
$$

Where $R G D P^{*}$ is natural log of real GDP, $\alpha^{*}$ is natural log of $\alpha$ or intercept term, $R C A P^{*}$ is natural $\log$ of real capital, $R E X^{*}$ is natural log of real official exchange rate, $R E X P^{*}$ is natural $\log$ of real exports and finally $\mu$ is error term.

\section{Estimation Procedures}

To explore the impact of capital, exchange rate and exports on economic development, we have followed autoregressive models.

$R G D P_{t}^{*}=\alpha^{*}+\beta R C A P_{t}^{*}+\gamma R E X_{t}^{*}+\delta R E X P_{t}^{*}+\chi A R(1)+\mu_{t}$

Where AR (1) is autoregressive term. In the presence of autoregressive term, our D.W Statistics will be inapplicable; we can utilize Breusch - Godfrey Serial Correlation LM Test. For detection of Heteroskedasticity, we may exercise Breusch - Pagan - Godfrey Test. Normal Distribution of the residuals has been examined by JarqueBera test. For Causal relationships among each set of two variables, we will bring into play Pairwise Granger Causality Test using the following equations.

$$
\begin{aligned}
& Y_{t}=a_{1}+\sum_{i=1}^{p} b_{i} X_{t-i}+\sum_{j=1}^{q} r_{i} Y_{t-j}+e_{1} \\
& X_{t}=a_{2}+\sum_{i=1}^{p} c_{i} Y_{t-i}+\sum_{j=1}^{q} d_{j} X_{t-j}+e_{2}
\end{aligned}
$$

\section{RESULTS AND Discussions}

In the table 1 given below, results are presented which are estimated by Ordinary Least Square method by including Autoregressive term. This table shows the names of variables, values of coefficients, standard errors, $t$ - 
statistic and probability values respectively in $1^{\text {st }}, 2^{\text {nd }}, 3^{\text {rd }}$, $4^{\text {th }}$ and $5^{\text {th }}$ columns. Values of $\mathrm{R}$ - squared, adjusted R squares, Probability of F - statistic and Durbin Watson statistics are given at the end of table.

With regards to real gross fixed capital formation that is used as a proxy to capital, results illustrate positive relation with real gross domestic product of China. Theoretically and econometrically it is logical and significant because it is statistically significant at 1 percent level and having more investment in the country will be cause of higher incomes as evident in the case of China. Investment in China has been a source of higher incomes from 1980s and now it is leading over world economy. Almost, 1 percent more investment in china may raise incomes by 0.26 percent on the average.

Real official exchange rate is also another important variable of higher incomes in open economy. As China is now operating in an open economy and exporting their products to all over the world economy. Negative and significant sign of this coefficient is proof that whenever there will be any increase in real official exchange rate, real income of China will decline. Due to increase in real exchange rate, real exports will decline and it will adversely affect income. On the average, one percent increase in real official exchange rate will lower real gross domestic product by 0.07 percent. The negative effect is so small but it takes an importance in the economy of any country.

Table 1: Results of Ordinary Least Square Method with Autoregressive term

\begin{tabular}{|c|c|c|c|c|}
\hline Variable & Coefficient & Std. Errors & T-statistic & Probability \\
\hline Constant & 10.58968 & 1.493350 & 7.091221 & 0.0000 \\
\hline $\begin{array}{c}\text { Real Gross Fixed } \\
\text { Capital Formation }\end{array}$ & 0.264466 & 0.034874 & 7.583501 & 0.0000 \\
\hline $\begin{array}{c}\text { Real Official } \\
\text { Exchange rate }\end{array}$ & -0.074582 & 0.034895 & -2.137325 & 0.0421 \\
\hline Real Exports & 0.057438 & 0.029001 & 1.980538 & 0.0583 \\
\hline AR(1) & 0.986139 & 0.007673 & 128.5146 & 0.0000 \\
\hline $\begin{array}{l}\text { R-squared } \\
\text { Prob(F-statistic) }\end{array}$ & $\begin{array}{l}0.999757 \\
0.000000\end{array}$ & $\begin{array}{c}\text { Adjusted R-squared } \\
\text { Durbin-Watson stat }\end{array}$ & $\begin{array}{c}0.999720 \\
1.671621\end{array}$ \\
\hline
\end{tabular}

\section{Note: Dependent variable: Real Gross Domestic} Product, Log - Log model

As expected from economic theory that real exports will always lead to higher real gross domestic products, this study has also found the same positive relationship from the analysis. Real gross domestic product will increase by 0.05 percent due to one percent increase in real exports of china. This variable is statistically significant at 5 percent level as well. Autoregressive term is turned out to be positive with significant coefficient value. Effects of other variables (that are not included in the regression model) are also positive as indicated with the sign of constant.

Probability of F - statistics is demonstrating that overall model is significant at 1 percent level. The values of $R-$ square and adjusted $\mathrm{R}$ - square are giving an idea of one of the econometric problems that is Multicollinearity. But it does not exist in this case due to not having few significant $\mathrm{t}$ - ratios.
Table 2: Test for Autocorrelation

Breusch-Godfrey Serial Correlation LM Test

\begin{tabular}{|l|l|l|}
\hline F-statistic & 1.093580 & Prob. F(2,24) \\
\hline
\end{tabular}

\begin{tabular}{l|l|l}
\hline Obs*R-squared & 2.589129 & Prob. Chi-Square(2) \\
\hline
\end{tabular}

0.3511

0.2740

Table 2 presents the results of Breusch - Godfrey Serial Correlation LM test that is used to detect autocorrelation problem because value of D.W is inapplicable whenever we include autoregressive term in our regression model. The results confirm the absence of Autocorrelation from this model and may not reject the Null Hypothesis (There is no problem of autocorrelation) of this test.

Table 3: Heteroskedasticity Test

Heteroskedasticity Test: Breusch-Pagan-Godfrey

\begin{tabular}{|l|l|l|}
\hline F-statistic & 1.105433 & Prob. F(3,27)
\end{tabular}

\begin{tabular}{|l|l|l|l|}
\hline Obs*R-squared & 3.391088 & Prob. Chi-Square(3) & 0.3352 \\
\hline
\end{tabular}

\begin{tabular}{|l|l|l|l|} 
Scaled explained SS & 1.864421 & Prob. Chi-Square(3) & 0.6010 \\
\hline
\end{tabular}

Breusch - Pagan - Godfrey test utilized to identify the problem of Heteroskedasticity in table 3. The values of result confirm that there is no Heteroskedasticity problem in the regression model.

\section{Figure 1: Normality test}

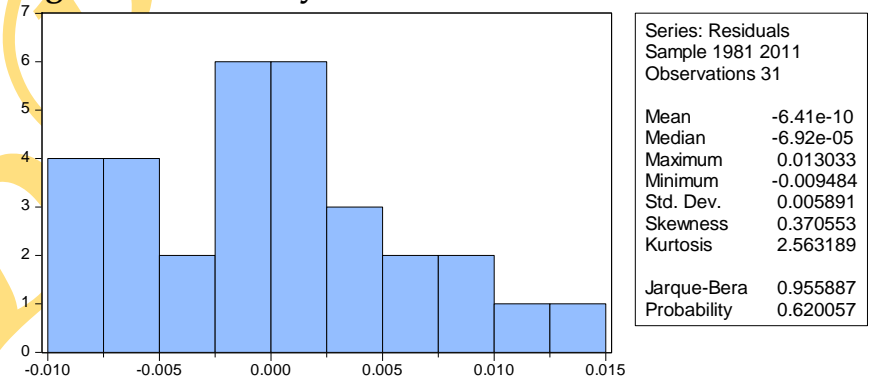

Figure 1 is the evidence that errors of regression equation are normally distributed. It is also confirm by the value of probability of Jarque - Bera test. On the basis of probability, the researcher may not reject the Null Hypothesis of this test (Errors are normally distributed) and confirm this evidence of normal distribution.

Table 4: Lag Selection Criteria

VAR Lag Order Selection Criteria

\begin{tabular}{|c|c|c|c|c|c|}
\hline Lag & LogL & LR & FPE & AIC & HQ \\
\hline $\mathbf{0}$ & 117.2286 & NA & $6.19 \mathrm{e}-09$ & -7.548575 & -7.488808 \\
$\mathbf{1}$ & 304.0460 & 311.3623 & $7.11 \mathrm{e}-14$ & -18.93640 & -18.63756 \\
$\mathbf{2}$ & 323.8040 & $27.66123^{*}$ & $5.89 \mathrm{e}-14^{*}$ & $-19.18694^{*}$ & $-18.64903^{*}$ \\
\hline
\end{tabular}

* indicates lag order selected by the criterion

LR: sequential modified LR test statistic (each test at 5\% level)

FPE: Final prediction error

AIC: Akaike information criterion

HQ: Hannan-Quinn information criterion

Granger Causality test among the set of variables is applied in the paper to examine the direction of causality. For this we need to determine the appropriate lag length. We have examined the appropriate lag length by using VAR test and finalized 2 as an appropriate lag for Granger Causality test in table 5. 
Table 5: Granger Causality test

\begin{tabular}{|c|c|c|}
\hline \multicolumn{3}{|l|}{ Pairwise Granger Causality Tests ( Lags: 2) } \\
\hline Null Hypothesis & F-Statistic & Probability \\
\hline LRGFCFCH does not Granger Cause LRGDPCH & 4.61519 & 0.0197 \\
\hline LRGDPCH does not Granger Cause LRGFCFCH & 6.47133 & 0.0054 \\
\hline LROEXR does not Granger Cause LRGDPCH & 1.27054 & 0.2982 \\
\hline LRGDPCH does not Granger Cause LROEXR & 8.45015 & 0.0016 \\
\hline LREXPTCH does not Granger Cause LRGDPCH & 0.75855 & 0.4788 \\
\hline LRGDPCH does not Granger Cause LREXPTCH & 3.65771 & 0.0404 \\
\hline LROEXR does not Granger Cause LRGFCFCH & 0.61733 & 0.5474 \\
\hline LRGFCFCH does not Granger Cause LROEXR & 7.08846 & 0.0036 \\
\hline LREXPTCH does not Granger Cause LRGFCFCH & 1.06460 & 0.3600 \\
\hline LRGFCFCH does not Granger Cause LREXPTCH & 4.09788 & 0.0289 \\
\hline LREXPTCH does not Granger Cause LROEXR & 8.30484 & 0.0017 \\
\hline LROEXR does not Granger Cause LREXPTCH & 4.95467 & 0.0154 \\
\hline
\end{tabular}

The results of granger causality test are arranged in table 5 . On the basis of probability values, we can decide about the direction of causality. This outcome explains the bi directional among real gross fixed capital formation and real gross domestic product. There is uni - directional causality between real gross domestic product and real official exchange rate of china. Uni - directional causality is also found from real gross domestic product to real exports. The study also finds uni - directional causality that runs from real gross fixed capital formation to real official exchange rate. It is also significantly proved that real gross fixed capital formation does granger cause real exports. Two - way granger causality is found among real exchange rate and real exports.

\section{CONCLUSION}

In this study, we have examined whether the rapid economic growth process in China can be explained by an investment-led growth effect, or export-led growth effect. Unlike others studies, we included investment and exports in our models, together with other relevant factors such as real official exchange rate. The reason for this was that investment has played an important role since the fifties when massive investment in infrastructure was made, which laid foundation for economic growth since 1978. As China is a large economy and it has interactions with other world big economies, we also included the real exchange rate in our study. Our empirical evidence show a positive relationship among labor productivity, exports and investment in the long run. An interesting result in the equilibrium is that exports show a greater effect on productivity than investment, and are likely associated with the economies of scale and the positive effects of spillovers from technology transfer, more efficient reallocation of resources, and competitiveness in the international market. In the dynamics, we found common positive effects of the lag of productivity and the R\&D effect on the productivity and investment equations in the short run. We also found that the real exchange rate plays an important role in determining the output level. Our findings are interesting in the sense that trade, exports, and investment all promotes productivity and output. However, exports seem to stimulate more productivity than output, reinforcing their role as a source of technological progress. In contrast, the real exchange rate has a negative and transitory effect.. Although our empirical analysis cannot disentangling whether the positive effect of investment on output and productivity is caused by an increase in capital accumulation or by improvements in total factor productivity or both, we can hypothesize that both channels are relevant because the labor productivity is increasing faster than the capitallabor ratio in the majority of the study period. Unlike others studies export exogenously drive output and productivity in the long run. This is a precondition to accept the export-led growth hypothesis and we have provided evidence in our model that exports exogenously drive growth. We have shown clear causality between exports and output or productivity.

Thus, the ratio of exports to GDP is increasing clearly during 1980-2010, while the ratio of investment to GDP is increasing during 1970s. This suggests that investment has been a permanent source of growth during above period, while exports as a source of growth appear to be especially relevant only during the post-reform period, initiated at the end of the seventies in China. In short, our results support the idea that the investment efforts and trade openness have played a significant role in China since the 1970s todate, and have encouraged output and productivity. Our findings suggest that investment and openness, especially exports, are jointly the most important determinants of productivity and output in the long run. These results are consistent with the theory that both export-led growth effect and an investment-led growth effect are significant in Chinese economic performance, and in accordance with the Schumpeterian version of the endogenous growth model, which suggests that trade and investment- oriented policies play an important role in economic growth process. In short, the pre-reform period has generated conducive environment for success of economic reforms introduced and executed since 1979.Other factors that expedited growth process are opening of economy, restructuring of public sector business organization and efficient allocation of resources to different sectors.

As all reforms were introduced under planned economic system and executed through public sector mechanism, it is a new experience in the history of economics. Previously, all economic growth miracles were taken place under free market mechanism. Similarly, during last two centuries, western hemisphere was the centre of economic growth but with the dawn of $21^{\text {st }}$ century it appears to be shifting to Asia. We can say that global economic paradigm is shifting and Asia will lead the world in future.

\section{REFERENCES}

Adams, F.G., B. Gangnes and Y. Shachmurove, 2006. Why china is so competitive? Measuring and explaining china's competitiveness. World Economy, 29: 95-122.

Arayama, Y. and K. Miyoshi, 2004. Regional diversity and sources of economic growth in China. World Economy, 27: 1583-1608. 
Bramall, C., 2000. Sources of Chinese Economic Growth 1978 to 1996. Studies in Contemporary China. Oxford University Press.

Chow, G., 1993. Capital formation and Economic Growth in China. The Quarterly Journal of Economics, 108: 809-842.

De Long, c.B., L. Summers and A.B. Abel, 1992. Equipment Investment and Economic Growth : how Strong is the nexus. Brookings Papers on economic activity: 157-211.

Domar,Evsey D. (1946) Capital Expansion, Rate of Growth and Employment.Econometrica,14. April,137-147.

Hendry, D.F. and G. Maison, 1993. Evaluating econometric models by encompassing the var. Models, methods and application of econometrics. Cambridge Mass: Essays in Honor of A.R.Bergstron MIT Press.

Hewitt, P. and P. Aghion, 1998. Capital accumulation and innovation as complementary factors in long-term growth. Journal of Economic Growth, 3: 111-130.

Horrod, Roy F (1939). An Essay in Dynamics Theory. Economic Journal,49,June,14-33.

Johansen, S., 1988. Statistical analysis of co- integration vector. Journal of Economic Dynamics and Control, 12: 231-254.

Johansen, S. and K. Juselius, 1990. Maximum likelihood estimation and inference on cointegration-with application to the demand for money. Oxford Bulletin of Economics and Statistics, 52: 231-254.

Johansen, S. and K. Juselius, 1994. Identification of the long-term and short-term structure: An application to the islm model. Journal of Econometrics, 63: 7-36.

Juselius, K., 2007. The co-integrated var model: Econometric methodology and applications. Oxford University Press.

Knight,Frank H. (1944). "Diminishing Return from Invesment. Journal of Political Economy,52,March,26-47.
Malthod, Thomas R (1798). An Essay on the Principle of Population. London: W.Pickering,1986.

Nielson, Ole E. Barndorff, 2004. "Power and Bipower Variation with Stochastic Volatility and Jumps," Journal of Financial Econometrics, Society for Financial Econometrics, vol. 2(1), pages 1-37.

Rahbek, A., E. Hansen and J.G. Dennnis, 2002. ARCH innovations and their impact on co-integration rank Testing, Department of Statistics and Operations, University of Copenhagen. Centre for analytical Finance.WP No. 22.

Ramsey, Frank (1928). A Mathematical Theory of Saving. Ecoomic Journal,38,December,543-559.

Recordo, David (1817) On the Principles of Political Economy and Taxation. Cambridge: Cambridge University Press, 1951.

Romer, P., 1986. Increasing returns and long-run growth. Journal of Economics Perspectives, 8: 3-22 Saleh-i-Martin Xavier \& Robert H.Barro. 2009. Economic Growth. India. New Delhi: PHI Learning.

Shan, J. and F.T. Sun, 1998. On the Export-led Growth hypothesis: the Economic evidence from China, Applied Economics 1055-1065.

Schumpeter,Joseph A (1934). The Theory of Economic Development. Cambridge:M.A.Harvard University Press.

Smith,Adam (1776) An Enquiry into the Nature and causes of the Wealth of Nations, New York: Random House,1937.

Solow Robert M (1956) A contribution to The Theory of Economic Growth. Quarterly Journal of Economics,70,Feburry,65-94.

\section{How to Cite}

Awan AG. 2014. Shifting Global Economic Paradigm Asian Business Review, 4, 35-40. 